\title{
Risk factors associated with failed transfer of passive immunity in male and female dairy calves: A 2008 retrospective cross-sectional study
}

\author{
D. L. Renaud, ${ }^{1 *} \odot$ K. M. Waalderbos, ${ }^{1}$ L. Beavers, ${ }^{2} \odot$ T. F. Duffield, ${ }^{1} \odot$ K. E. Leslie, ${ }^{1}$ and M. C. Windeyer ${ }^{3}$ \\ ${ }^{1}$ Department of Population Medicine, University of Guelph, Guelph, ON, Canada, N1G 2W1 \\ ${ }^{2}$ Lactanet Canada, Guelph, ON, Canada, N1E 1N4 \\ ${ }^{3}$ Department of Production Animal Health, University of Calgary, Calgary, AB, Canada, T2N 1N4
}

\section{ABSTRACT}

This retrospective cross-sectional study was designed to identify risk factors associated with failed transfer of passive immunity (FTPI) and to determine differences in colostrum management between male and female dairy calves. Research technicians visited a total of 16 commercial dairy farms weekly. For each calf born on these farms, the farm personnel completed a birth record to document the colostrum management practices provided, level of calving assistance, calf sex, and time of birth. On the weekly visits to the farms, the technicians collected blood from calves that were 1 to $7 \mathrm{~d}$ of age. Serum was separated via centrifugation and the concentration of serum total protein (STP) was determined using a digital refractometer. Failed transfer of passive immunity was defined as calves having an STP of $<5.2 \mathrm{~g} / \mathrm{dL}$. Data were available for 1,778 calves aged 1 to $7 \mathrm{~d}$. Several differences were observed with respect to how male and female calves were managed. Male calves were more likely to receive a lower volume of colostrum, have colostrum delivered using a nipple bottle followed by an esophageal tube feeder, be fed pooled colostrum, and receive fresh colostrum rather than frozen colostrum relative to female calves. Serum total protein (STP) ranged from 3.6 to $9.7 \mathrm{~g} / \mathrm{dL}$ with a mean of $5.7 \mathrm{~g} / \mathrm{dL}$ (standard deviation, $0.7 \mathrm{~g} / \mathrm{dL}$ ) and $21.1 \%$ of the calves had FTPI. Using a mixed linear regression model, we identified that a calf being male $(-0.14 \mathrm{~g} / \mathrm{dL})$, being delivered by a hard pull $(-0.23 \mathrm{~g} /$ $\mathrm{dL}$ ), and receiving the first feeding colostrum from a combination of a nipple bottle followed by an esophageal tube feeder $(-0.12 \mathrm{~g} / \mathrm{dL})$ were associated with a lower concentration of STP. Feeding $6 \mathrm{~L}$ or more of colostrum in the first $24 \mathrm{~h}$ of life was associated with a $0.14 \mathrm{~g} / \mathrm{dL}$ higher concentration of STP compared with feeding $<3.9 \mathrm{~L}$ of colostrum. For FTPI, being delivered

Received August 4, 2019.

Accepted December 8, 2019.

${ }^{*}$ Corresponding author: renaudd@uoguelph.ca by a hard pull [odds ratio (OR) 2.21] and receiving the first feeding colostrum from a nipple bottle followed by an esophageal tube feeder (OR 1.83) were associated with higher odds of FTPI. Feeding $>6 \mathrm{~L}$ of colostrum in the first $24 \mathrm{~h}$ of life was associated with a reduced odds (OR 0.65) of FTPI compared with feeding $<3.9 \mathrm{~L}$ of colostrum. This study highlights the importance of certain management practices in reducing FTPI incidence and identifies discrepancies in colostrum management between male and female dairy calves.

Key words: passive immunity, calf, serum total protein, colostrum management

\section{INTRODUCTION}

Colostrum management is one of the most important practices for successful rearing of dairy calves (Godden et al., 2019). Calves are born agammaglobulinemic due to the placental separation of maternal and fetal blood supply (Arthur et al., 1996), and they are reliant on the consumption of colostrum to provide immunoglobulins and other nutrients to protect against disease-causing pathogens (Cortese, 2009). Without adequate absorption of immunoglobulins, calves will develop failed transfer of passive immunity (FTPI).

Several methods have been validated to identify calves with FTPI by directly or indirectly measuring the levels of IgG. Radial immunodiffusion is the reference test for detecting FTPI, and it directly measures the concentration of IgG (Beam et al., 2009). A serum IgG of $<10 \mathrm{~g} / \mathrm{L}$ has traditionally been used to indicate FTPI in dairy calves (Weaver et al., 2000). A challenge with using radial immunodiffusion is that blood must be sent to a referral laboratory, which delays diagnosis of FTPI and has a high cost. Consequently, indirect measures are commonly used due to their practicality and lower cost. Serum total protein (STP) determined by refractometry is an indirect measure of IgG and has been shown to be well correlated $(r \geq 0.88)$ with immunoglobulin concentrations measured by radial immunodiffusion in dairy calves (Naylor and Kronfeld, 1977; 
Wilm et al., 2018). A level of STP between 5.2 and 5.5 $\mathrm{g} / \mathrm{dL}$ indicates that calves have FTPI with reasonable sensitivity and specificity (Buczinski et al., 2018).

Failed transfer of passive immunity has many consequences. A recent meta-analysis identified that if a dairy or beef calf has FTPI, it is 2 times as likely to die, 1.8 times as likely to be treated for respiratory disease, and 1.5 times as likely to be treated for diarrhea as an animal without FTPI (Raboisson et al., 2016). In terms of growth, the impact of FTPI has been found to be relatively small and may not be economically important (Windeyer et al., 2014; Cuttance et al., 2018).

Four important factors that could reduce FTPI incidence are associated with improved serum IgG: (1) the quantity of colostrum fed, (2) the quality of colostrum fed, (3) the timing of feeding, and (4) the cleanliness of colostrum (Godden et al., 2019). A suggested dose of colostrum of 8.5 to $10 \%$ of BW should be given to provide a sufficient quantity of IgG (Godden, 2008; Conneely et al., 2014). Colostrum that contains $>50 \mathrm{~g} / \mathrm{L}$ of $\mathrm{IgG}$ is considered high-quality dairy colostrum. For every $10 \mathrm{~g} / \mathrm{L}$ increase in colostral IgG, serum IgG was shown to increase by $1.1 \mathrm{~g} / \mathrm{L}$, highlighting that betterquality colostrum is associated with better transfer of passive immunity (Shivley et al., 2018; Godden et al., 2019). Feeding calves colostrum within $4 \mathrm{~h}$ after birth is commonly recommended (Stott et al., 1979; Michanek et al., 1989); however, Fischer et al. (2018) reported that IgG absorption is much higher if the first feeding is provided within the first $2 \mathrm{~h}$ after calving, and Shivley et al. (2018) found that for every hour delay in the provision of colostrum, serum IgG declines by 0.32 $\mathrm{g} / \mathrm{L}$. These reports suggest that even a 4-h delay may have an important impact on the absorption of IgG. For cleanliness, several studies have reported a negative association between colostral bacterial concentration and the level of serum IgG (James et al., 1981; Staley and Bush, 1985; Godden et al., 2012), but the level of bacterial contamination that results in these consequences is unclear.

A further factor that may influence the levels of serum $\operatorname{IgG}$ is the sex of the calf. Several studies have identified that female calves may receive preferential treatment, with less contaminated and higher volumes of colostrum (Fecteau et al., 2002; Shivley et al., 2019). Additionally, $7 \%$ of surveyed Canadian dairy producers reported that they did not always provide colostrum to male dairy calves (Renaud et al., 2017). The effect that this differential treatment may have on the levels of STP and FTPI is unclear, and further exploration is required.

To further substantiate which factors are associated with the levels of STP and FTPI in dairy calves, we conducted a large-scale retrospective cross-sectional study. Specifically, our objectives were to determine differences in colostrum management between male and female dairy calves and to identify risk factors associated with STP and FTPI in Ontario, Canada.

\section{MATERIALS AND METHODS}

\section{Animals, Housing, and Management}

This study enrolled neonatal calves from 16 commercial dairy farms in southwestern Ontario, as previously reported (Windeyer et al., 2012, 2014; McCorquodale et al., 2013; Murray et al., 2014). This study was approved by the University of Guelph Animal Care Committee. A convenience sample of farms was selected with the assistance of local veterinarians, and farms were included in the study if they were within $250 \mathrm{~km}$ of the University of Guelph (Guelph, ON, Canada). As previously described, study farms were larger than the average dairy farm and milked a mean of 238 cows (median, 150 cows; range, 40-750 cows). Most farms housed their cows in freestalls $(81 \%)$, compared with tiestalls (19\%). The study farms had a 305-d average milk production of $10,056 \mathrm{~kg}$. The farms had a range of different calf housing styles. Calves were kept in individual pens, hutches, group pens, and a combination of housing styles on $38,25,6$, and $32 \%$ of farms, respectively. Most study farms (44\%) used a combination of straw and shavings for bedding, whereas 38\% used straw alone and $13 \%$ used only shavings.

\section{Study Enrollment and Sampling}

From January to December of 2008, female and male calves from 1 to $7 \mathrm{~d}$ of age were enrolled. All calves that were on the farm and born since the previous visit were enrolled in the study during weekly farm visits by research technicians. Calves were uniquely identified with the National Livestock Identification for Dairy tags at each farm.

Farm personnel were requested to complete a birth record for each live-born calf using forms provided (Windeyer, 2012). The birth record contained detailed information about the delivery of the calf, calving environment, colostrum management practices, and perinatal treatments administered to each calf (Supplemental File S1; https://doi.org/10.3168/jds.2019-17397).

During each weekly visit, research technicians collected a blood sample by jugular venipuncture from each calf that was 1 to $7 \mathrm{~d}$ of age. A 20-gauge, 1-inch hypodermic needle (BD Vacutainer Precision Glide, 
Becton, Dickinson and Co., Franklin Lakes, NJ) was used to draw $10 \mathrm{~mL}$ of blood into a sterile glass serum Vacutainer without anticoagulant (Becton, Dickinson and Co.). The blood samples were stored in coolers with an ice pack and transported to the laboratory for processing. Serum was harvested from the blood samples via centrifugation and used to assess STP with a digital refractometer (model 300027, Sper Scientific Ltd., Scottsdale, AZ) at room temperature. The refractometer was recalibrated with distilled water each day before use.

\section{Statistical Analysis}

All statistical analyses were completed using Stata 14 (StataCorp LP, College Station, TX). Data were imported from Excel (Microsoft, Redmond, WA) into Stata 14 and checked for completeness. Descriptive statistics were generated for all variables in the data set. Calves with missing data were deleted from analysis (complete-case analysis; Pigott, 2001). Differences in calf sex with respective categorical variables describing colostrum management were examined using chi-squared test, whereas continuous variables were examined using simple mixed linear regression models.

Two explanatory models were created to explore the concentration of STP and odds of FTPI. A mixed linear regression model was created to evaluate factors associated with the concentration of STP, and a mixed logistic regression model was created to determine variables associated with FTPI. Failed transfer of passive immunity was defined as a STP $<5.2 \mathrm{~g} / \mathrm{dL}$ (Buczinski et al., 2018). In both models, dairy farm was used as a random effect for unmeasured factors that were not controlled for on the dairy farms. The assumption of linearity of continuous variables was assessed by plotting STP against the variable in the linear regression model. Whereas, for the logistic regression model, the assumption of linearity of continuous explanatory variables was assessed by plotting the natural logarithm of the odds of the outcome against the variable. If a variable failed to meet the linearity assumption, the variable was categorized. Collinearity among the explanatory variables was tested using Spearman rank coefficients. If the correlation coefficient between 2 variables was $\geq 0.7$, only one variable was retained based on lowest Akaike's information criterion. Univariable regression models were constructed to screen for variables that were unconditionally associated with the outcome using a liberal $P$-value of 0.2 . Factors potentially associated with the outcome were subsequently offered to a multivariable model through a manual backward stepwise process. Confounding effects were evaluated by examining the effect of removing the variables on the coefficients of the remaining variables. A variable was deemed a confounder if it was not an intervening variable based on the causal diagram and the coefficient of a significant variable in the model changed $\geq 20 \%$. Two-way interactions were evaluated between biologically important variables and remained in the final models if significant $(P$-value $<0.05$; Dohoo et al., 2010). Homoscedasticity and normality of the residuals and the best linear unbiased predictors were used to evaluate model fit.

\section{RESULTS}

Data from a total of 2,204 calves aged 1 to $7 \mathrm{~d}$ from 16 commercial dairy farms in southwestern Ontario were available for analysis. A total of 426 calves were eliminated from the data set due to missing data, leaving 1,778 calves with complete data. Of the calves available for this retrospective analysis, 1,198 (67\%) were female and $580(33 \%)$ were male. The discrepancy of enrollment by sex could have been due to the use of sexed semen or because few farms retained male calves beyond a few days of age, which meant that many male calves were sold before the regular weekly technician visit to the farm. The mean age at enrollment was $4.6 \mathrm{~d}$ of age [standard deviation (SD), 2.1 d]. The majority (36\%) of calves were enrolled in the summer months (June to August) followed by spring months (March to May; $29 \%$ ), fall months (September to November; 21\%), and winter months (December to February; 14\%). Only 66 calves $(3.7 \%)$ were born in a multiple birth. The majority of calves were born in the designated maternity area (93\%), with only $5 \%$ born in freestalls and $2 \%$ born in tiestalls. The calving process was unobserved for $58 \%$ of calves, observed but unassisted for $11 \%$ of calves, and required an easy pull for $24 \%$ of calves. Hard pulls or veterinary assistance was only required for $7 \%$ of calves. Most calves (30\%) were born between 0400 and $1000 \mathrm{~h}$, whereas 29,21 , and $20 \%$ of calves were born between 1000 and 16:00 h, 2200 and 0400 h, and 1600 and $2200 \mathrm{~h}$, respectively.

\section{Colostrum Feeding Practices}

Colostrum management information was captured for most of the calves, using the individual calf birth records. Most calves (59\%) were fed colostrum by the farm personnel once in the first $24 \mathrm{~h}$. Only 31 and $10 \%$ of calves received 2 feedings of colostrum or 3 or more feedings of colostrum in the first $24 \mathrm{~h}$, respectively. Calves received a mean of $5.3 \mathrm{~L}(\mathrm{SD}, 1.6 \mathrm{~L})$ of colostrum in the first $24 \mathrm{~h}$ after calving. Pooled colostrum was 
provided to $71 \%$ of calves, whereas colostrum from the dam was provided to $27 \%$ of calves, colostrum replacer was provided to $1.5 \%$ of calves, and a combination of sources was provided to $0.9 \%$ of calves. Fresh, previously frozen, pasteurized, or a combination of different colostrum types was provided to $63,3.4,34$, and $0.5 \%$ of calves, respectively. Most colostrum was delivered using an esophageal tube feeder $(53 \%)$ followed by a nipple bottle $(32 \%)$, combination of a nipple bottle followed by an esophageal tube feeder $(13 \%)$, and a bucket or suckling the dam $(2 \%)$. Most colostrum was fed to the calves within the same-day quartile time period that they were born (64\%). However, 31 and $5 \%$ of calves received colostrum 1 and 2 periods after they were born, respectively. Calves were most commonly removed from their dam within the same-day quartile time period that they were born (65\%), whereas 13 and $22 \%$ of calves were removed 1 and 2 time periods after they were born, respectively.

\section{Differences in Colostrum Feeding Practices by Calf Sex}

Several differences were observed with respect to how male and female calves were managed (Table 1). The route of colostrum delivery, colostrum source, time to removal from the dam, and storage type of colostrum fed were different between the sexes. Time of colos- trum delivery, however, did not differ between male and female calves. In terms of the volume of colostrum delivered in the first $24 \mathrm{~h}$ of life, male calves received $0.21 \mathrm{~L}$ less colostrum (95\% CI, 0.07-0.35 L; $P=0.003$ ) than female calves.

\section{Concentration of STP and FTPI}

Concentration of STP for 1,760 calves 1 to $7 \mathrm{~d}$ of age were available and ranged from 3.6 to $9.7 \mathrm{~g} / \mathrm{dL}$, with a mean of $5.7 \mathrm{~g} / \mathrm{dL}$ (SD: $0.7 \mathrm{~g} / \mathrm{dL}$ ). Using a cutoff of $<5.2$ $\mathrm{g} / \mathrm{dL}$, we identified that 371 calves $(21.1 \%)$ had FTPI.

In the mixed linear regression model, the variables that were unconditionally associated with the level of STP were calf sex, calving location, level of calving assistance, timing of colostrum feeding, volume and type of colostrum fed, route of delivery, timing of removal from dam, and age at collection of blood sample. In the final multivariable model, 5 variables were retained (Table 2).

In the mixed logistic regression model evaluating factors associated with FTPI, calving location, level of calving assistance, being a twin, characteristics (volume, source, and type) of colostrum fed, route of delivery, timing of removal from dam, and age at collection of blood sample were unconditionally associated with the outcome. In the final model, 4 variables were associated with FTPI (Table 3).

Table 1. Univariable analysis of colostrum feeding practices differentiated by sex from birth records of 1,778 calves born on 16 commercial dairy farms in southwestern Ontario

\begin{tabular}{|c|c|c|c|c|}
\hline Management practices & Description & $\begin{array}{c}\text { Male } \\
\text { no. }(\%)\end{array}$ & $\begin{array}{l}\text { Female } \\
\text { no. }(\%)\end{array}$ & $P$-value \\
\hline \multirow[t]{3}{*}{ Time to colostrum feeding } & Same time period as born ${ }^{1}$ & $364(65)$ & $728(63)$ & \multirow[t]{3}{*}{0.40} \\
\hline & One time period after birth ${ }^{2}$ & $163(29)$ & $372(32)$ & \\
\hline & Two time periods after birth ${ }^{3}$ & $32(6)$ & $57(5)$ & \\
\hline \multirow[t]{3}{*}{ Removal from dam } & Same time period as born ${ }^{1}$ & $323(65)$ & $713(65)$ & \multirow[t]{3}{*}{$<0.001$} \\
\hline & One time period after birth ${ }^{2}$ & $43(9)$ & $160(15)$ & \\
\hline & Two time periods after birth ${ }^{3}$ & $135(27)$ & $221(20)$ & \\
\hline \multirow[t]{4}{*}{ Route of colostrum delivery } & Nipple bottle & $165(29)$ & $387(33)$ & \multirow[t]{4}{*}{$<0.001$} \\
\hline & Esophageal tube feeder & $277(49)$ & $653(55)$ & \\
\hline & Bucket or left to suckle dam & $13(2)$ & $17(1)$ & \\
\hline & Nipple bottle then tube feeder & $108(19)$ & $125(11)$ & \\
\hline \multirow[t]{4}{*}{ Colostrum source } & Dam & $106(19)$ & $360(31)$ & \multirow[t]{4}{*}{$<0.001$} \\
\hline & Pooled colostrum & $450(80)$ & $789(67)$ & \\
\hline & Colostrum replacer & $0.3(5)$ & $23(2)$ & \\
\hline & Combination of sources & $6(1)$ & $0.9(8)$ & \\
\hline \multirow[t]{4}{*}{ Storage type of colostrum } & Fresh & $362(65)$ & $703(61)$ & \multirow[t]{4}{*}{$<0.001$} \\
\hline & Frozen & $7(1)$ & $50(4)$ & \\
\hline & Pasteurized & $179(32)$ & $392(34)$ & \\
\hline & Combination & $8(1)$ & $0(0)$ & \\
\hline
\end{tabular}

${ }^{1}$ The calf was fed colostrum or removed from the dam in the same time period as was born. For example, if the calf was born between 0400 and $1000 \mathrm{~h}$, it was fed colostrum between 0400 to $1000 \mathrm{~h}$.

${ }^{2}$ The calf was fed colostrum or removed from dam 1 time period after birth. For example, if the calf was born between 0400 and $1000 \mathrm{~h}$, it was fed colostrum between 1000 and $1600 \mathrm{~h}$.

${ }^{3}$ The calf was fed colostrum or removed from dam 2 time periods after birth. For example, if the calf was born between 0400 and $1000 \mathrm{~h}$, it was fed colostrum between 1600 and $2200 \mathrm{~h}$. 
Table 2. Results from a mixed linear regression model identifying factors associated with the concentration of serum total protein in calves aged 1 to $7 \mathrm{~d}$ from 16 commercial dairy farms in southwestern Ontario

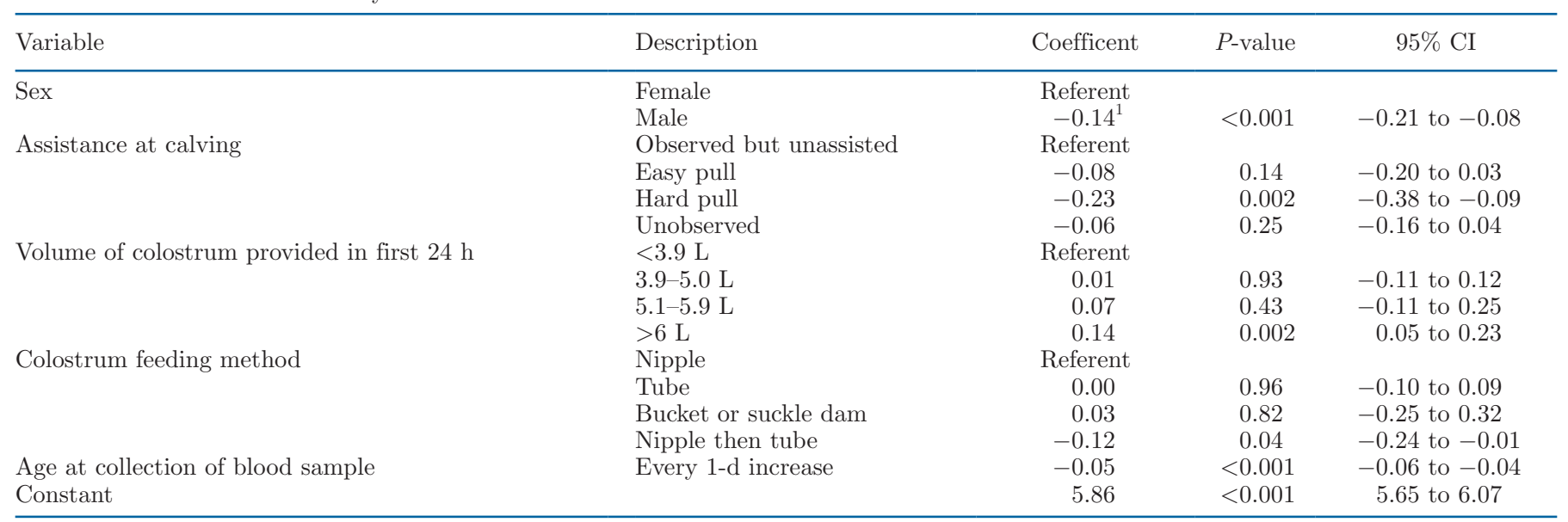

${ }^{1}$ Example interpretation: Male calves had a $0.14 \mathrm{~g} / \mathrm{dL}$ lower serum total protein than female calves.

\section{DISCUSSION}

The purpose of this study was to determine differences in the colostrum management of male and female calves and determine practices associated with STP and FTPI. We identified that male calves have lower concentrations of STP than female dairy calves and some differential treatment exists between sexes. We also found that significant assistance provided at calving, colostrum feeding method used, and the volume of colostrum provided in the first $24 \mathrm{~h}$ after calving affect both the level of STP and the odds of having FTPI. A limitation to consider when interpreting the results of this study is that the information collected at birth was recorded by farm personnel, which could have affected the accuracy of reporting. Specifically, the Hawthorne effect could have occurred whereby farm personnel recorded more positive outcomes because they knew researchers were evaluating the information (Parsons, 1974; Gillespie, 1991). The inability to control for colostrum quality could have also affected the results because the level of IgG in colostrum has been found to influence the level of STP and FTPI (Shivley et al., 2018; Godden et al., 2019).

Despite this study being completed in 2008, the results remain meaningful. A recent survey of 52 Ontario dairy producers identified several similarities with respect to colostrum management (Renaud et al., 2018). The proportion of farms that used fresh colostrum and nipple and tube feeders to deliver colostrum remained similar between the studies, as did the timing of colostrum delivery. However, the number of farms feeding

Table 3. Results from a mixed logistic regression model identifying factors associated with failed transfer of passive immunity (serum total protein concentration $<5.2 \mathrm{~g} / \mathrm{dL}$ ) in calves aged 1 to $7 \mathrm{~d}$ from 16 commercial dairy farms in southwestern Ontario

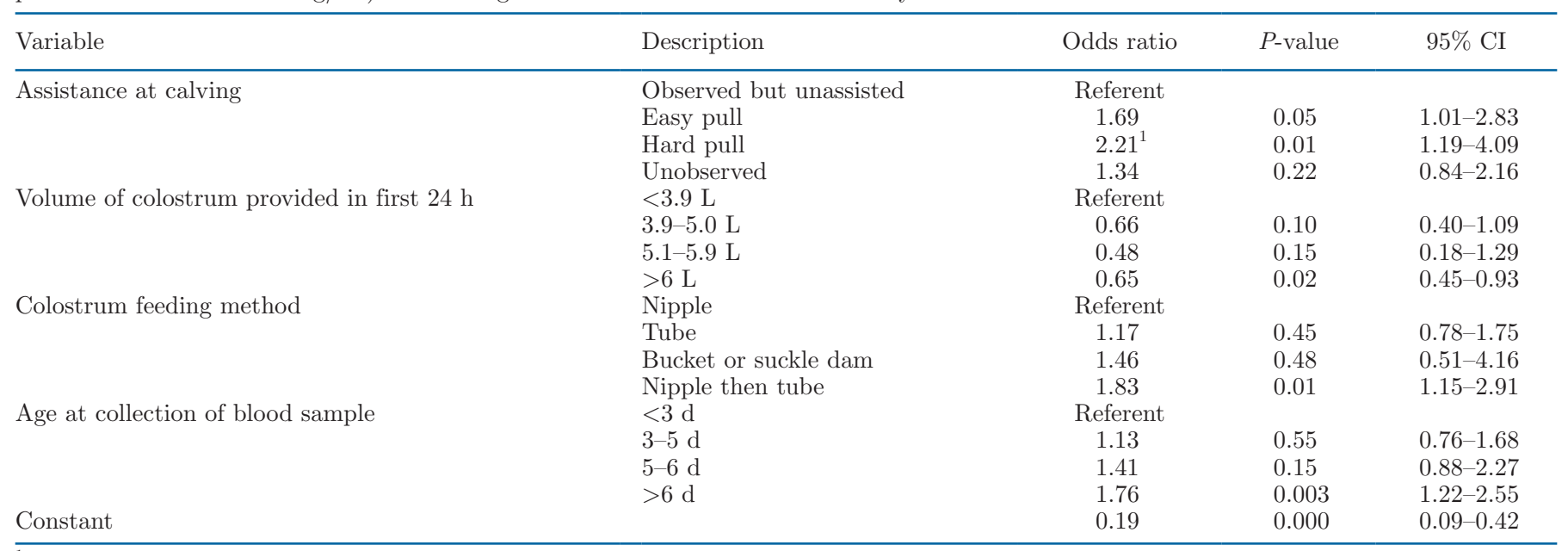

${ }^{1}$ Example interpretation: Calves requiring a hard pull to be delivered had a 2.21 times greater odds of having failed transfer of passive immunity. 
a second feeding of colostrum was higher in the recent study. Despite this difference, the results of this study likely remain currently applicable.

This study identified that male calves were less likely to receive frozen colostrum and more likely to have colostrum delivered using a combination of a nipple bottle followed by an esophageal tube feeder, be fed pooled colostrum, and receive a lower total volume of colostrum relative to female calves. These results are similar to studies conducted in the United States and Canada in which differential treatment of male calves was reported. In a survey of more than 1,000 Canadian producers, Renaud et al. (2017) identified that $7 \%$ of male calves did not always receiving colostrum and $17 \%$ of male calves received differing levels of nutrition compared with female calves. Through a survey of 42 dairy operations in the United States, Shivley et al. (2019) found that male calves received a lower volume of colostrum and were more likely to receive colostrum by suckling from the dam compared with their female counterparts. From a practical perspective, however, the impact of these differences is unclear because the $0.14 \mathrm{~g} / \mathrm{dL}$ difference in STP found in the current study likely does not have biological significance. More work is necessary to explore the effect that these differences have on male calf health, welfare, and productivity, and to determine factors that may influence the dairy producers' care of the male calves, including the price paid for the calves.

A higher volume of colostrum fed in the first $24 \mathrm{~h}$ after calving had a positive association with STP and led to reduced odds of FTPI. The importance of colostrum volume on successful transfer of passive immunity has been previously demonstrated (Chigerwe et al., 2008; Lora et al., 2018) and is likely due to an increased mass of IgG being ingested by the calf. Despite this clear association between volume of colostrum fed and transfer of passive immunity, many producers may not be providing an ample quantity of colostrum, with $26 \%$ of 52 farms surveyed in Ontario, Canada providing $<3 \mathrm{~L}$ of colostrum and $25 \%$ of the over 100 Canadian dairy producers surveyed feeding $<4 \mathrm{~L}$ of colostrum in the first $24 \mathrm{~h}$ after birth (Vasseur et al., 2010; Renaud et al., 2017). Additional knowledge mobilization measures need to be conducted to ensure that producers receive the message about the importance of feeding a sufficient volume of colostrum.

Calves with difficult births (delivered as a hard pull or through the use of surgery or were malpresented) had lower STP and increased odds of FTPI. These results are in agreement with other published studies. Beam et al. (2009) identified that the odds of FPTI were higher for calves when supplemental heat was not provided following dystocia, whereas Waldner and
Rosengren (2009) found that dystocia was associated with a lower serum concentration of IgG in beef calves. Difficult births have also been associated with an increased risk of respiratory acidosis, as well as reduced vigor and suckling ability leading to a reduced apparent absorption efficiency of immunoglobulins (Murray and Leslie, 2013; Murray et al., 2015; Homerosky et al., 2017). These findings suggest that improving the management of calves born following dystocia, such as the provision of a nonsteroidal anti-inflammatory drug (Murray et al., 2016) or supplemental heat (Mee, 2008), could lead to improved transfer of passive immunity. The findings also suggest that given the higher risk of FTPI associated with dystocia, producers should have a greater focus on providing colostrum to these calves.

The practice of switching from a nipple bottle to an esophageal tube feeder for first colostrum feeding after calving was associated with a lower STP and higher odds of FTPI. The reasons for this association are unclear but could reflect a lack of patience or an inability of the calf to effectively suckle due to poor vigor (Murray and Leslie, 2013). As calves with poor vigor or vitality can be identified through their visual appearance, initiation of movement, responsiveness, oxygenation, and heart and respiratory rate (Murray, 2014), using early interventions such as nonsteroidal anti-inflammatory drugs (Murray et al., 2016) could limit the negative impacts on the transfer of passive immunity.

\section{CONCLUSIONS}

Successful transfer of passive immunity is vital to ensuring the health and survival of neonatal dairy calves. This study indicates that male calves received differing management practices at birth compared with female calves; however, the effect of these differences is unclear because only a small difference in STP was found between male and female calves. Calves offered more colostrum at birth had a higher level of STP and lower odds of FTPI, whereas calves that were born by hard pull or surgery or had a malpresentation subsequently had a reduced level of STP and increased odds of FTPI. With respect to colostrum delivery, using a nipple bottle then switching to an esophageal tube feeder was associated with less successful transfer of passive immunity. Because of the importance of passive immunity, these factors should be considered when delivering colostrum to calves.

\section{ACKNOWLEDGMENTS}

We thank the dairy producers that participated in this study as well as the Ontario Ministry of Agricul- 
ture and Rural Affairs (Guelph, ON, Canada) for the funding provided. The authors have not stated any conflicts of interest.

\section{REFERENCES}

Arthur, G. H., D. E. Nokes, and H. Pearson. 1996. The development of the conceptus. Pages 51-109 in Pregnancy and Parturition in Veterinary Reproduction and Obstetrics. 7th ed. W. B. Saunders, Philadelphia, PA.

Beam, A. L., J. E. Lombard, C. A. Kopral, L. P. Garber, A. L. Winter, J. A. Hicks, and J. L. Schlater. 2009. Prevalence of failure of passive transfer of immunity in newborn heifer calves and associated management practices on US dairy operations. J. Dairy Sci. 92:3973-3980. https://doi.org/10.3168/jds.2009-2225.

Buczinski, S., E. Gicquel, G. Fecteau, Y. Takwoingi, M. Chigerwe, and J. M. Vandeweerd. 2018. Systematic review and meta-analysis of diagnostic accuracy of serum refractometry and brix refractometry for the diagnosis of inadequate transfer of passive immunity in calves. J. Vet. Intern. Med. 32:474-483. https://doi.org/10.1111/ jvim.14893.

Chigerwe, M., J. Tyler, L. Schultz, J. Middleton, B. Steevens, and J. Spain. 2008. Effect of colostrum administration by use of oroesophageal intubation on serum IgG concentrations in Holstein bull calves. Am. J. Vet. Res. 69:1158-1163. https://doi.org/10 .2460 /ajvr.69.9.1158.

Conneely, M., D. P. Berry, J. P. Murphy, I. Lorenz, M. L. Doherty, and E. Kennedy. 2014. Effect of feeding colostrum at different volumes and subsequent number of transition milk feeds on the serum immunoglobulin $\mathrm{G}$ concentration and health status of dairy calves. J. Dairy Sci. 97:6991-7000. https://doi.org/10.3168/jds.2013-7494.

Cortese, V. S. 2009. Neonatal immunology. Vet. Clin. North Am. Food Anim. Pract. 25:221-227. https://doi.org/10.1016/j.cvfa.2008.10 .003.

Cuttance, E. L., W. A. Mason, R. A. Laven, and C. V. C. Phyn. 2018. The relationship between failure of passive transfer and mortality, farmer-recorded animal health events and body weights of calves from birth until 12 months of age on pasture-based, seasonal calving dairy farms in New Zealand. Vet. J. 236:4-11. https://doi.org/ 10.1016/j.tvjl.2018.04.005.

Dohoo, I., W. Martin, and H. Stryhn. 2010. Model-building strategies. Pages 365-394 in Veterinary Epidemiological Research. 2nd ed. VER Inc., Charlottetown, PEI, Canada.

Fecteau, G., P. Baillargeon, R. Higgins, J. Paré, and M. Fortin. 2002. Bacterial contamination of colostrum fed to newborn calves in Québec dairy herds. Can. Vet. J. 43:523-527.

Fischer, A. J., Y. Song, Z. He, D. M. Haines, L. L. Guan, and M. A. Steele. 2018. Effect of delaying colostrum feeding on passive transfer and intestinal bacterial colonization in neonatal male Holstein calves. J. Dairy Sci. 101:3099-3109. https://doi.org/10.3168/jds .2017-13397.

Gillespie, R. 1991. Manufacturing Knowledge: A History of Hawthorne Experiments. Cambridge University Press, UK.

Godden, S. 2008. Colostrum management for dairy calves. Vet. Clin. North Am. Food Anim. Pract. 24:19-39. https://doi.org/10.1016/ j.cvfa.2007.10.005.

Godden, S. M., J. E. Lombard, and A. R. Woolums. 2019. Colostrum management for dairy calves. Vet. Clin. North Am. Food Anim. Pract. 35:535-556. https://doi.org/10.1016/j.cvfa.2019.07.005.

Godden, S. M., D. J. Smolenski, M. Donahue, J. M. Oakes, R. Bey, S. Wells, S. Sreevatsan, S. Stabel, and J. Fetrow. 2012. Heat-treated colostrum and reduced morbidity in preweaned dairy calves: Results of a randomized trial and examination of mechanisms of effectiveness. J. Dairy Sci. 95:4029-4040. https://doi.org/10.3168/ jds.2011-5275.

Homerosky, E. R., E. Timsit, E. A. Pajor, J. P. Kastelic, and M. C. Windeyer. 2017. Predictors and impacts of colostrum consumption by $4 \mathrm{~h}$ after birth in newborn beef calves. Vet. J. 228:1-6. https:/ /doi.org/10.1016/j.tvjl.2017.09.003.
James, R. E., C. E. Polan, and K. A. Cummins. 1981. Influence of administered indigenous microorganisms on uptake of [iodine-125] gamma-globulin in vivo by intestinal segments of neonatal calves. J. Dairy Sci. 64:52-61. https://doi.org/10.3168/jds.S0022 $-0302(81) 82528-3$.

Lora, I., A. Barberio, B. Contiero, P. Paparella, L. Bonfanti, M. Brscic, A. L. Stefani, and F. Gottardo. 2018. Factors associated with passive immunity transfer in dairy calves: Combined effect of delivery time, amount and quality of the first colostrum meal. Animal 12:1041-1049. https://doi.org/10.1017/S1751731117002579.

McCorquodale, C. E., A. Sewalem, F. Miglior, D. Kelton, A. Robinson, A. Koeck, and K. E. Leslie. 2013. Short communication: Analysis of health and survival in a population of Ontario Holstein heifer calves. J. Dairy Sci. 96:1880-1885. https://doi.org/10.3168/ jds.2012-5735.

Mee, J. F. 2008. Newborn dairy calf management. Vet. Clin. North Am. Food Anim. Pract. 24:1-17. https://doi.org/10.1016/j.cvfa .2007.10.002.

Michanek, P., M. Ventorp, and B. Weström. 1989. Intestinal transmission of macromolecules in newborn dairy calves of different ages at first feeding. Res. Vet. Sci. 46:375-379. https://doi.org/10.1016/ S0034-5288(18)31183-4.

Murray, C. F. 2014. Characteristics, risk factors and management programs for vitality of newborn dairy calves. $\mathrm{PhD}$ Thesis. Univ. of Guelph, Guelph, ON, Canada.

Murray, C. F., T. F. Duffield, D. B. Haley, D. L. Pearl, D. M. Veira, S. M. Deelen, and K. E. Leslie. 2016. The effect of meloxicam NSAID therapy on the change in vigor, suckling reflex, blood gas measures, milk intake, and other variables in newborn dairy calves. J. Vet. Sci. Anim. Husband. 4:1-14.

Murray, C. F., and K. E. Leslie. 2013. Newborn calf vitality: Risk factors, characteristics, assessment, resulting outcomes and strategies for improvement. Vet. J. 198:322-328. https://doi.org/10.1016/j .tvjl.2013.06.007.

Murray, C. F., D. M. Veira, A. L. Nadalin, D. M. Haines, M. L. Jackson, D. L. Pearl, and K. E. Leslie. 2015. The effect of dystocia on physiological and behavioral characteristics related to vitality and passive transfer of immunoglobulins in newborn Holstein calves. Can. J. Vet. Res. 79:109-119.

Murray, C. F., M. C. Windeyer, T. F. Duffield, D. B. Haley, D. L. Pearl, K. M. Waalderbos, and K. E. Leslie. 2014. Associations of serum haptoglobin in newborn dairy calves with health, growth, and mortality up to 4 months of age. J. Dairy Sci. 97:7844-7855. https://doi.org/10.3168/jds.2014-8465.

Naylor, J. M., and D. S. Kronfeld. 1977. Refractometry as a measure of the immunoglobulin status of the newborn dairy calf: Comparison with zinc sulfate turbidity test and single radial immunodiffusion. Am. J. Vet. Res. 38:1331-1334.

Parsons, H. M. 1974. What happened at Hawthorne?: New evidence suggests the Hawthorne effect resulted from operant reinforcement contingencies. Science 183:922-932. https://doi.org/10.1126/ science.183.4128.922.

Raboisson, D., P. Trillat, and C. Cahuzac. 2016. Failure of passive immune transfer in calves: A meta-analysis on the consequences and assessment of the economic impact. PLoS One 11:e0150452. https: //doi.org/10.1371/journal.pone.0150452.

Renaud, D. L., T. F. Duffield, S. J. LeBlanc, D. B. Haley, and D. F. Kelton. 2017. Management practices for male calves on Canadian dairy farms. J. Dairy Sci. 100:6862-6871. https://doi.org/10.3168/ jds.2017-12750.

Renaud, D. L., D. F. Kelton, S. J. LeBlanc, D. B. Haley, and T. F. Duffield. 2018. Calf management risk factors on dairy farms associated with male calf mortality on veal farms. J. Dairy Sci. 101:1785-1794. https://doi.org/10.3168/jds.2017-13578.

Shivley, C. B., J. E. Lombard, N. J. Urie, D. M. Haines, R. Sargent, C. A. Kopral, T. J. Earleywine, J. D. Olson, and F. B. Garry. 2018. Preweaned heifer management on US dairy operations: Part II. Factors associated with colostrum quality and passive transfer status of dairy heifer calves. J. Dairy Sci. 101:9185-9198. https:// doi.org/10.3168/jds.2017-14008. 
Shivley, C. B., J. E. Lombard, N. J. Urie, D. M. Weary, and M. A. G. von Keyserlingk. 2019. Management of preweaned bull calves on dairy operations in the United States. J. Dairy Sci. 102:4489-4497. https://doi.org/10.3168/jds.2018-15100.

Staley, T. E., and L. J. Bush. 1985. Receptor mechanisms of the neonatal intestine and their relationship to $\mathrm{Ig}$ absorption and disease. J. Dairy Sci. 68:184-205. https://doi.org/10.3168/jds.S0022 $-0302(85) 80812-2$.

Stott, G. H., D. B. Marx, B. E. Menefee, and G. T. Nightengale. 1979. Colostral immunoglobulin transfer in calves: II. The rate of absorption. J. Dairy Sci. 62:1766-1773. https://doi.org/10.3168/ jds.S0022-0302(79)83495-5.

Vasseur, E., F. Borderas, R. I. Cue, D. Lefebvre, D. Pellerin, J. Rushen, K. M. Wade, and A. M. de Passillé. 2010. A survey of dairy calf management practices in Canada that affect animal welfare. J. Dairy Sci. 93:1307-1315. https://doi.org/10.3168/jds.2009-2429.

Waldner, C. L., and L. B. Rosengren. 2009. Factors associated with serum immunoglobulin levels in beef calves from Alberta and Saskatchewan and association between passive transfer and health outcomes. Can. Vet. J. 50:275-281.

Weaver, D. M., J. W. Tyler, D. C. VanMetre, D. E. Hostetler, and G. M. Barrington. 2000. Passive transfer of colostral immunoglobulins in calves. J. Vet. Intern. Med. 14:569-577. https://doi.org/10 .1111/j.1939-1676.2000.tb02278.x.

Wilm, J., J. H. C. Costa, H. W. Neave, D. M. Weary, and M. A. G. von Keyserlingk. 2018. Technical note: Serum total protein and immunoglobulin $\mathrm{G}$ concentrations in neonatal dairy calves over the first 10 days of age. J. Dairy Sci. 101:6430-6436. https://doi.org/ $10.3168 /$ jds.2017-13553.

Windeyer, M. C. 2012. Vaccination and risk factors for bovine respiratory disease in dairy calves. DVSc Thesis. Univ. of Guelph, Guelph, ON, Canada.

Windeyer, M. C., K. E. Leslie, S. M. Godden, D. C. Hodgins, K. D. Lissemore, and S. J. LeBlanc. 2012. The effects of viral vaccination of dairy heifer calves on the incidence of respiratory disease, mortality, and growth. J. Dairy Sci. 95:6731-6739. https://doi.org/10 $.3168 /$ jds.2012-5828.

Windeyer, M. C., K. E. Leslie, S. M. Godden, D. C. Hodgins, K. D. Lissemore, and S. J. LeBlanc. 2014. Factors associated with morbidity, mortality, and growth in dairy heifer calves up to 3 months of age. Prev. Vet. Med. 113:231-240. https://doi.org/10.1016/j .prevetmed.2013.10.019.

\section{ORCIDS}

D. L. Renaud () https://orcid.org/0000-0002-3439-3987

L. Beavers $\odot$ https://orcid.org/0000-0001-7205-9114

T. F. Duffield (๑ https://orcid.org/0000-0001-6035-4669 